\title{
Legal Protection of Health Personnel during the Management of the Covid 19 Pandemic
}

\author{
Eka Poedjihartanto $\mathrm{P}^{1}$, Zudan Arif Fakrulloh ${ }^{2}$ \\ \{Eka_poedjihartanto@yahoo.com ${ }^{1}$,cclsis@yahoo.com² ${ }^{2}$, \\ Universitas Borobudur, Jakarta, Indonesia ${ }^{1,2}$
}

\begin{abstract}
Health personnel were on the front lines of the COVID-19 pandemic at the time, with a high chance of the virus spreading. Legal protection for health workers is occasionally disregarded, as though the community is unconcerned and believes it is part of a medical worker's responsibilities. Health professionals are subject to legal protection under Law No. 36 of 2014 concerning Health Professionals, which establishes Professional Standards, Professional Service Standards, and Standard Operating Procedures. In practice, however, officeholders have not completely implemented legislative safeguards. The study looks on how health staff are legally protected throughout the treatment of the covid-19 pandemic, as well as the challenges they face in getting work safety and health guarantees during the epidemic. With data acquired from literature research, this study utilized a normative legal method to find out and understand the legal protection of health staff during the treatment of the covid-19 outbreak. According to the findings of our research on health workers, legal protection has only been gained, particularly in the form of monitoring and advice, but there are still flaws in the legal protection efforts offered since certain health workers' rights have not been fulfilled.
\end{abstract}

Keywords: Protection; Law; Health Workers

\section{Introduction}

Of course, health professionals are on the front lines of the COVID-19 pandemic, with a high risk of spreading the virus. However, legal protection for health workers in charge of dealing with the COVID-19 pandemic is sometimes overlooked, as though the public is indifferent and believes that it is already a medical worker's job and obligation to deal with the COVID-19 pandemic. The preamble of the 1945 Constitution clearly defines the Indonesian people's aspirations as well as the country's national goals. Protecting the whole Indonesian country and homeland, promoting public welfare, educating the nation's youth, and contributing to the formation of a world order based on freedom, everlasting peace, and social justice are the national goals. This is a form of country-building. Health development is a part of national development that attempts to increase public awareness, willingness, and capacity to live a healthy lifestyle for all people in order to attain the greatest possible public health and create productive human resources. 
The fundamental principle of justice is the recognition that all human beings have the same dignity. In addition, all humans have the rights that they get, in addition to commitments that must be fulfilled in order for them to become a part of life. The most fundamental rights are aspects of human nature or humanity itself. The humanity of every human being is a mandate and a noble idea from God who wants every human being to grow and develop in his life to reach and achieve his perfection as a human being. Therefore, every human being must have his dignity protected before the law in order to obtain equality.

Basically, legal protection is part of an action or effort in order to provide protection to the community from arbitrary actions that are not in accordance with the rule of law or who are irresponsible, to create order and peace so as to enable the community to get their honor as human beings. The same may be said for health personnel who are working to expedite the treatment of Covid-19. Health professionals, as one component of health resources, have a responsibility to do their tasks professionally. Given that these health professionals are legal persons, a legal connection is formed between them, their patients, and the health facilities in which they operate. Where the legal connection speaks of rights and responsibilities between parties who are legal subjects in order to achieve reciprocity, one party's rights become the other party's obligations and vice versa. So, in essence, health personnel in our country are entitled to legal protection since they have fulfilled their responsibilities.

The administration should be able to ensure that the community's right to health is protected by providing health services that are fair, equitable, adequate, affordable, and of high quality. One kind of protection for health personnel in doing their tasks is the provision of PPE (Personal Protective Equipment), however this has not been fully implemented. The welfare state will not be fulfilled until the right to health is respected. As the bearer of the mandate for the community's welfare, the state is obligated to respect, preserve, and fulfill these human rights to health in order to meet their basic requirements as a provider of health services. From the description above, the researcher is interested in conducting research and taking the title "Legal Protection of Health Workers During the Handling of the Covid 19 Pandemic".

\section{Results and Discussion}

\subsection{During the Covid-19 Pandemic, Health-Care Workers Have Legal Protection}

Indonesia adopted legal protection for health professionals in Law Number 36 of 2009 on Health in Writing, which states that health workers have the right to compensation and legal protection when doing their tasks in accordance with their profession. The entitlement of health professionals to legal protection in the course of their job is re-emphasized in Law Number 36 of 2014 Concerning Health Workers, as long as they carry out their tasks in line with Operational Standards. So, on the basis of the above legislation, in handling COVID-19, the government's position as the one who assigns health workers has the responsibility and authority to be able to carry out regulations made by the government itself, in providing guarantees of legal protection to health workers in charge of handling COVID-19. Satjipto Raharjo understands that legal protection can provide guidance for human rights that can harm others and getting a protection that can be given to the community so that they can enjoy all the rights granted by law. According to Steven J. Heyman, legal protection has three main elements:

a. Legal protection is related to the position/condition of the individual, which means the position of the individual as a free person and citizen. 
b. Legal protection is related to substantive rights, which means the law recognizes and guarantees individuals' rights to life, liberty, and property.

c. The most basic understanding of legal protection is related to the enforcement of rights, namely the special way in which the government prevents acts of violation of substantive rights, corrects, and provides penalties for such violations.

According to Soedikno Mertokusumo, legal protection is a guarantee of human rights and obligations in order to fulfill their own interests and in human relations. According to Sukendar and Aris, legal protection facilities are divided into 2 (two) types, namely: (a) Preventive legal protection is a step or method taken to prevent an event that has legal consequences. (b) Repressive legal protection is a step or method taken if an event that results in the law has occurred.

Preventative measures include Presidential Decree Number 02 of 2020 about the Task Force for Accelerating Covid-19 Handling and Minister of Health Regulation Number 09 of 2020 concerning Guidelines for Large-Scale Social Restrictions in the Context of Accelerating Covid-19 Handling. Repressively to guarantee the rights of health workers, the Government issues policies, including; Decrees of the Minister of Health Number HK. 01.07/MENKES/278/2020 concerning the Provision of Death Incentives and Compensation for Health Workers Handling Covid-19, and Decrees of the Minister of Health Number HK. 01.07/MENKES/215/2020 concerning the Use of the Special Allocation Fund for the Health Sector for the Prevention and Handling of Covid-19 for the 2020 Fiscal Year.

The role and responsibility of the state to carry out the mandated provisions must be carried out because this is a legal obligation that affects the rights of health workers that must be fulfilled. Once again, that legal protection is always related to rights and obligations. The nonfulfillment of rights and obligations of course has legal consequences. Legal protection for citizens from government actions in principle has the following objectives:

a. Legal safeguards are in place to guarantee that people' interests are protected.

b. Legal protection in order to prevent actions that harm the rights of citizens.

c. Legal protection provides citizens with access to stop violations, obtain compensation or redress for violations of their rights.

d. Legal protection in ensuring the availability of compensation or remedial action against the rights of citizens who have been harmed.

Regarding the implementation of the above, the facts that occur in the field in terms of the legal protection of health workers, there are still some discrepancies with those mandated by the Legislation. The government through existing regulations, although directly the form of protection is not confirmed in a regulation. This protection may be found in the guidelines on aid workers' duties when performing their duties as a task force for the expedited treatment of Covid-19. The government and health workers must complement each other to create a balance of rights and obligations, but the legal protection provided still has a weakness. So that the government seems unable to provide legal protection for health workers in charge of handling Covid-19.

\subsection{Constraints of Health Workers in Obtaining Occupational Safety and Health Guarantees during the Handling of the Covid-19 Pandemic}

Everyone has the right to health, according to Health Law Number 36 of 2009, and the government is accountable for the provision of all types of quality, safe, efficient, and economical health initiatives. Meanwhile, Disaster Management Law No. 24 of 2017 specifies that the government is responsible for safeguarding the community from catastrophes while 
conducting disaster management. Because the Covid-19 epidemic is one of the worldwide tragedies that has affected the whole globe, including Indonesia, health professionals ought to be provided with health and safety assurances so that they may accomplish health development. Occupational safety and health is defined as "all activities that ensure and protect the safety and health of workers through efforts to prevent work accidents and occupational diseases," according to Article 1 of Government Regulation Number 50 of 2002 concerning the Implementation of Occupational Health and Safety Management Systems.

Occupational safety and health is an understanding and hard work to ensure the physical and spiritual integrity and excellence of the workplace in particular and humanity at large, their collaboration and civilization, in order to create a prosperous and prosperous society. Scientific understanding is a science and its application in order to prevent the possibility of accidents and occupational diseases, whereas scientific understanding is a science and its application in order to prevent the possibility of accidents and occupational diseases. Exposure to workers (medical, paramedical, and non-medical personnel) in health facilities in an environment contaminated with germs originating from patients receiving treatment or being treated, transitions in the epidemiology of diseases and health problems. This is followed by the entry of advanced science and technology that demands skilled and skilled workers so that it cannot always be met with the risk of work accidents.

Every employee has the right to work in a safe and healthy environment. The government has ensured occupational safety and health for health professionals in the task force for the acceleration of handling Covid-19 in the regulations governed by the government indicated above, but the facts on the ground still face various hurdles. That there are still impediments in the working group for the expedited handling of Covid-19 in satisfying occupational safety and health guarantees for health personnel. A convoluted local govt system is to blame for many of roadblocks encountered. Furthermore, health workers who work in the response team for the expedited ability to handle of Covid-19 have not been provided with occupational safety guarantees, with only Items (Protective Equipment), Nutrients, food, and Home Stay being supplied while still on duty, even though BPJS is funded by there own agencies instead of the municipal authorities.

The Regional Government provides occupational safety and health protection to health workers handling Covid-19 while on duty, as required by law, but the guarantee and protection are still subject to obstacles, including those caused by the regional government's bureaucracy, which is extremely complicated. Regarding the uneven distribution of personal protective equipment (PPE) among on-duty health personnel. These health personnel have not received any health and safety guarantees as members of the task group tasked with expediting the management of Covid-19 throughout its introduction. Only a few of them receive assurances in the shape of personal protective equipment, vitamins, meals, and home stays.

\section{Conclusion}

In dealing with the covid-19 outbreak, Indonesia has provided legal protection for health personnel, in its implementation health workers have received legal protection such as forms of supervision and guidance, of course what is expected by health workers is not only this, there are several rights of health workers that have not been fulfilled, such as intensive and assistance. death has not been obtained by health workers. This is an imbalance in providing legal protection to health workers. Where the government must be present here, be it the central government, local government or work units. Health professionals' limitations in getting 
workplace safety and health assurances during the Covid-19 outbreak, are caused by the very long and complicated bureaucracy of the Regional Government itself, and the uneven delivery of PPE to health workers on duty. As workers who are given the authority to carry out the task of accelerating the handling of Covid-19, in practice, Occupational health and safety assurances have not been provided to health personnel. Only a few get guarantees in the form of PPE, vitamins, food and temporary shelter, but not all health workers get it. It is the responsibility of the government to carry out orders that have not been carried out in their entirety.

\section{References}

[1] A'an Efendi, and Freddy Purnomo, 2017, Administrative Law, Jakarta: Sinar Graphic.

[2] Burhan Ashsofah, 2010, Legal Research Methods, Jakarta: Rineka Cipta.

[3] Salim and Erlies, 2013, Application of Legal Theory in Thesis and Dissertation Research, Jakarta: Rajawali Pers.

[4] Satjipto Rahardjo, 2000, Legal Studies, Bandung: Citra Aditya Bakti.

[5] Setiono, 2004, Rule of Law (Supremacy of Law, Surakarta: Master of Law in the Postgraduate Program at Sebelas Maret University.

[6] Soedikno Mertokusumo, 1991, Knowing the Law (An Introduction), Yogyakarta: Liberty.

[7] Sukendar, and Aris Prio Agus Santoso, 2019, Crime in Independent Nursing Practice (Legal Protection for Nurses and Patients), Yogyakarta: Nuha Medika. Sugiyono, 2001, Research Methods, Bandung: CV Alfa Beta.

[8] RI, 1945 Constitution.

[9] RI, Law Number 1 of 1970 concerning Occupational Safety.

[10] RI, Law Number 13 of 2003 concerning Manpower.

[11] RI, Law Number 36 Year 2009 concerning Health.

[12] RI, Law Number 36 of 2014 concerning Health Workers.

[13] RI, Law Number 24 of 2017 concerning Disaster Management.

[14] RI, Government Regulation Number 50 of 2002 concerning the Implementation of Occupational Health and Safety Management Systems.

[15] RI, Presidential Decree Number 2 of 2020 concerning the Task Force for the Acceleration of Handling Covid-19.

[16] RI, Regulation of the Minister of Health Number 9 of 2020 concerning Guidelines for Large-Scale Social Restrictions in the Context of Accelerating Handling of Covid-19.

[17] RI, Decree of the Minister of Health Number HK. 01.07/MENKES/215/2020 concerning the Utilization of the Special Allocation Fund for the Health Sector for the Prevention and Handling of Covid-19 for the 2020 Fiscal Year.

[18] RI, Decree of the Minister of Health Number HK. 01.07/MENKES/278/2020 concerning Provision of Incentives and Death Compensation for Health Workers Handling Covid19. 